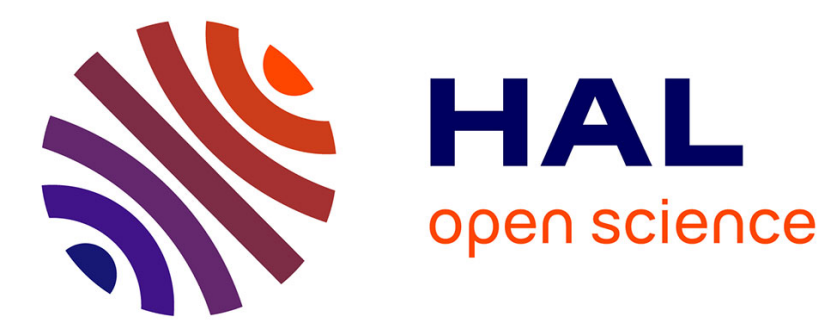

\title{
Removal of NO by simultaneous action of dielectric-barrier discharge and $\mathrm{TiO}$ photocatalyst
}

I. Jõgi, V. Bichevin, M. Laan, A. Haljaste, H. Käämbre, V. Sabre

\section{To cite this version:}

I. Jõgi, V. Bichevin, M. Laan, A. Haljaste, H. Käämbre, et al.. Removal of NO by simultaneous action of dielectric-barrier discharge and TiO photocatalyst. European Physical Journal: Applied Physics, 2009, 47 (2), pp.1-5. 10.1051/epjap/2009089 . hal-00489486

\section{HAL Id: hal-00489486 https://hal.science/hal-00489486}

Submitted on 5 Jun 2010

HAL is a multi-disciplinary open access archive for the deposit and dissemination of scientific research documents, whether they are published or not. The documents may come from teaching and research institutions in France or abroad, or from public or private research centers.
L'archive ouverte pluridisciplinaire HAL, est destinée au dépôt et à la diffusion de documents scientifiques de niveau recherche, publiés ou non, émanant des établissements d'enseignement et de recherche français ou étrangers, des laboratoires publics ou privés. 


\title{
Removal of NO by simultaneous action of dielectric-barrier discharge and $\mathrm{TiO}_{2}$ photocatalyst
}

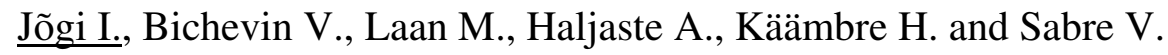 \\ Institute of Physics, University of Tartu, Tähe 4, 51010, ESTONIA \\ indrek.jogi@ut.ee, Tel: +372 737 5564,fax: +372 7375858
}

\begin{abstract}
NO oxidation by simultaneous action of a dielectric barrier discharge and $\mathrm{TiO}_{2}$ photocatalyst was investigated as a function of the inlet gas composition $\left(\mathrm{NO}, \mathrm{O}_{2}, \mathrm{~N}_{2}\right.$ ) and the input energy. Concentrations of various $\mathrm{NO}_{\mathrm{x}}$ species and ozone in the outlet were detected by the optical absorption spectroscopy. Higher content of $\mathrm{O}_{2}(10 \%$ and higher) increased the removal of $\mathrm{NO}$ and resulted in a higher output of $\mathrm{N}_{2} \mathrm{O}_{5}$. $\mathrm{TiO}_{2}$ coating on a reactor electrode resulted in the time-depending oxidation of NO. Initially the concentration of untreated NO fell below the level achieved without $\mathrm{TiO}_{2}$ but after few minutes the positive effect of $\mathrm{TiO}_{2}$ diminished. The initial decrease in NO level due to the presence of $\mathrm{TiO}_{2}$ coating is explainable by surface reactions of $\mathrm{NO}$ species and absorbed oxygen. After few minutes, the surface states responsible for the initial removal of NO saturated and the effect of $\mathrm{TiO}_{2}$ vanished.
\end{abstract}

PACS codes: 52.80.Tn, 82.33.Xj, 82.65.+r

Title: Removal of NO simultaneously by dielectric-barrier discharge and $\mathrm{TiO}_{2}$

\section{INTRODUCTION}

$\mathrm{NO}_{\mathrm{x}}$ is a harmful by-product in flue gases whereas $\mathrm{NO}$ is the most abundant $\mathrm{NO}_{\mathrm{x}}$ species. Non-thermal plasma sources, such as corona discharge or dielectric barrier discharge (DBD) are considered as an efficient method for the treatment of $\mathrm{NO}_{\mathrm{x}}$ [1-6]. Another possibility for 
the treatment of $\mathrm{NO}_{\mathrm{x}}$ is to use photocatalysts, such as $\mathrm{TiO}_{2}$ [6-8]. The main route for the removal of $\mathrm{NO}$ from flue gases is the oxidation of $\mathrm{NO}$ to $\mathrm{NO}_{2}$. In the case of plasma, $\mathrm{NO}_{2}$ can be further oxidized to $\mathrm{NO}_{3}$ and finally to $\mathrm{N}_{2} \mathrm{O}_{5}$ [3,4]. It has been reported that the simultaneous action of DBD and $\mathrm{TiO}_{2}$ coating inside the reactor decreases in the outlet both $\mathrm{NO}$ and $\mathrm{NO}_{\mathrm{x}}$ concentrations [9-12]. In these studies only $\mathrm{NO}$ and $\mathrm{NO}_{2}$ concentrations were measured and it was not clear whether $\mathrm{NO}_{\mathrm{x}}$ was adsorbed on the $\mathrm{TiO}_{2}$ surface, oxidized to $\mathrm{NO}_{3}$ and $\mathrm{N}_{2} \mathrm{O}_{5}$ or reduced to $\mathrm{N}_{2}$ and $\mathrm{O}_{2}$.

The aim of the present study was to investigate the effect of $\mathrm{TiO}_{2}$-coated $\mathrm{DBD}$ electrode on the removal of $\mathrm{NO}_{\mathrm{x}}$ using different $\mathrm{NO}$ and $\mathrm{O}_{2}$ concentrations in the inlet gas mixture and varying the specific input energy. The effect of $\mathrm{TiO}_{2}$ on the oxidation of $\mathrm{NO}$ was studied by recording the final concentrations of different $\mathrm{NO}_{\mathrm{x}}$ species $\left(\mathrm{NO}, \mathrm{NO}_{2}, \mathrm{NO}_{3}, \mathrm{~N}_{2} \mathrm{O}_{5}\right)$.

\section{EXPERIMENTAL SETUP AND METHODS}

The experimental setup is shown in Figure 1. All experiments were carried out at atmospheric pressure. The mixture of $\mathrm{NO} / \mathrm{O}_{2} / \mathrm{N}_{2}$ was prepared from separate gases of $\mathrm{N}_{2}, \mathrm{O}_{2}$ and $450 \mathrm{ppm}$ $\mathrm{NO}$ in $\mathrm{N}_{2}$ by the use of flow controllers. The inlet fractional concentration of NO was varied in the range of $0-450 \mathrm{ppm}$; the percentage of oxygen was $0,5,10$ or $20 \%$. The total flow rate, $F_{r}$, was varied from 0.9 to $2.21 / \mathrm{min}$.

Figure 1 gives a schematic representation of experimental set-up. DBD reactor had a coaxial design. The inner electrode of the reactor was a stainless steel tube, whose outer diameter was $14 \mathrm{~mm}$. The outer electrode was a winding on the quartz tube. The discharge gap spacing was approximately $0.7 \mathrm{~mm}$. The length of the active discharge region was approximately 100 mm. A commercial Degussa $\mathrm{P}_{25} \mathrm{TiO}_{2}$ powder (grains of $80 \%$ of anatase and $20 \%$ of rutile) was pressed on the inner electrode or painted on it using a mixture prepared by stirring the powder in water or ethanol. In the latter case, the mass of the $\mathrm{TiO}_{2}$ coating was varied by using different number of painting steps.

The barrier discharge was ignited applying to the inner electrode voltage pulses, $V$, of $\approx 15 \mu \mathrm{s}$ half-width and 1-2 kHz repetition rate. The peak value of pulses was varied from 5 to $10 \mathrm{kV}$. The outer electrode was grounded through a $23 \mathrm{nF}$ capacitance. The voltage, $V$, was measured by the capacitive voltage divider 1 . The charge transferred through the discharge during one voltage pulse, was measured by the capacitor 2 . The voltages were recorded by the PC oscilloscope PCS 500. 
The mean input power, $P$, was calculated from the recorded Lissajous figures according to the procedure described in a paper of Rousseau et al. [13]. The specific input energy, SIE, was calculated according to the formula $S I E=P / F_{r}$. Details about the waveforms of the voltage pulses and determination of SIE are described elsewhere [14].

Concentrations of $\mathrm{NO}_{\mathrm{x}}$ species and ozone were measured at the outlet of the reactor by the optical absorption spectroscopy (OAS) method and by an electrochemical gas detector QRAE+ 2000 (only for determination of NO concentration). The OAS measurement setup consisted from radiation source (a deuterium or a tungsten lamp), an absorption cell of $10 \mathrm{~cm}$ length, a spectrometer MDR-23 and a CCD camera system Alta U1107. The wavelengths region of $200-230 \mathrm{~nm}$ was used for the determination of $\mathrm{NO}, \mathrm{N}_{2} \mathrm{O}_{5}$ and $\mathrm{O}_{3}$ concentrations. The region of $400-430 \mathrm{~nm}$ was used for the determination of $\mathrm{NO}_{2}$ concentration. The detection of $\mathrm{NO}_{3}$ by absorption in 640-670 nm region was not successful. Unless specified otherwise, the concentrations of $\mathrm{NO}_{\mathrm{x}}$ species and $\mathrm{O}_{3}$ were determined from spectra obtained after 2 minutes of reactor's work.

\section{RESULTS AND DISCUSSION}

\subsection{Removal of $\mathrm{NO}$ without the $\mathrm{TiO}_{2}$ coating}

At a fixed gas composition and varying flow rate, $F_{r}$, voltage, $V$, and repetition rate, $f$, it appeared that the remaining concentration of NO depended only on SIE (Fig. 2a) and not separately on the parameters counted above. Thus, similarly to earlier studies [2], SIE is a relevant parameter controlling the NO removal. As expected, at the same SIE, the concentration of untreated NO was higher for higher initial concentrations of NO.

There was a slight discrepancy in the concentrations of NO measured by chemical NO analyzer and OAS method and this discrepancy is most likely due to the remnant NO signal of the NO analyzer.

Fig. 3 shows that at $330 \mathrm{ppm}$ fraction of $\mathrm{NO}$ and at $5 \%$ of $\mathrm{O}_{2}$, NO was only partially converted to $\mathrm{NO}_{2}$ while both $\mathrm{N}_{2} \mathrm{O}_{5}$ and $\mathrm{O}_{3}$ were practically missing. It should be pointed that in the absence of $\mathrm{NO}$ in the initial mixture, the $\mathrm{O}_{3}$ was present also in the mixtures with $5 \%$ of $\mathrm{O}_{2}$ [14]. Higher $\mathrm{O}_{2}$ percentage resulted in the total removal of $\mathrm{NO}$ and both $\mathrm{O}_{3}$ and $\mathrm{N}_{2} \mathrm{O}_{5}$ became detectable (fig. 3b). 
These results indicate that at lower concentrations of $\mathrm{O}_{2}$, both $\mathrm{O}$ and $\mathrm{O}_{3}$ produced in plasma are totally removed by reactions

$$
\mathrm{NO}+\mathrm{O}+\mathrm{M} \rightarrow \mathrm{NO}_{2}+\mathrm{M} \text { and } \mathrm{NO}+\mathrm{O}_{3} \rightarrow \mathrm{NO}_{2}+\mathrm{O}_{2}[3,5]
$$

and because of the depletion of $\mathrm{O}$ atoms, $\mathrm{N}_{2} \mathrm{O}_{5}$ was not found. At higher percentage of oxygen, $\mathrm{NO}_{2}$ is further oxidized to $\mathrm{NO}_{3}$ and $\mathrm{N}_{2} \mathrm{O}_{5}$ by the reactions

$$
\mathrm{NO}_{2}+\mathrm{O}+\mathrm{M} \rightarrow \mathrm{NO}_{3}+\mathrm{M}, \mathrm{NO}_{3}+\mathrm{NO}_{2}+\mathrm{M} \rightarrow \mathrm{N}_{2} \mathrm{O}_{5}+\mathrm{M}[3,5]
$$

The rate constant of reaction

$$
\mathrm{NO}_{2}+\mathrm{O}_{3} \rightarrow \mathrm{NO}_{3}+\mathrm{O}_{2}[5]
$$

is small and it was not considered. The oxidation of $\mathrm{NO}$ to $\mathrm{NO}_{2}$ proceeds until $\mathrm{NO}$ is totally removed and thus there appear only $\mathrm{NO}_{2}, \mathrm{~N}_{2} \mathrm{O}_{5}$ and $\mathrm{O}_{3}$ in the outlet.

\subsection{Removal of $\mathrm{NO}$ in the presence of $\mathrm{TiO}_{2}$ photocatalyst}

The $\mathrm{TiO}_{2}$ coating increased the removal of $\mathrm{NO}$ during the first few minutes of reactor operation, whereas later the concentration of NO increased again and reached a constant value (Fig. 4a). The effect of $\mathrm{TiO}_{2}$ on the removal of NO increased with the increasing mass of the $\mathrm{TiO}_{2}$ coating (not shown) and with the increase of SIE injected into the reactor (Fig. 4a). At energies below $100 \mathrm{~J} / 1$, the effect of $\mathrm{TiO}_{2}$ was negligible. The dependence of $\mathrm{NO}$ removal on the $\mathrm{TiO}_{2}$ mass indicates that the surface of $\mathrm{TiO}_{2}$ is involved in the process. In the absence of $\mathrm{O}_{2}$, the presence of $\mathrm{TiO}_{2}$ coating had no effect on the removal of NO. Thus, the oxygen is involved in the initial increase in the removal of NO.

The temporal change of the concentrations of different $\mathrm{NO}_{\mathrm{x}}$ species and ozone is demonstrated in figure 4. After $15 \mathrm{~s}$ of the reactor operation, the concentrations of NO and $\mathrm{NO}_{2}$ were low (Fig. 4b-c) whereas the concentration of ozone was high. The concentration of $\mathrm{NO}_{2}$ increased with time while the $\mathrm{O}_{3}$ concentration decreased. When the resources of $\mathrm{O}_{3}$ were exhausted, $\mathrm{NO}_{2}$ concentration reached a constant level. After this moment, $\mathrm{NO}$ concentration also started to increase. The time period after which the concentration of $\mathrm{O}_{3}$ diminished and that of $\mathrm{NO}_{2}$ reached saturation, increased with the increasing concentration of $\mathrm{O}_{2}$ and with the decrease of the initial concentration of NO. The NO concentration remained always below the detection limit if the concentration of $\mathrm{O}_{2}$ was $10 \%$. 
After 2 minutes of reactor's work the concentrations of $\mathrm{NO}_{\mathrm{x}}$ species and $\mathrm{O}_{3}$ stabilized. Compared to the case of uncoated electrodes (Fig. 3), the presence of $\mathrm{TiO}_{2}$ resulted in the lower final concentration of $\mathrm{O}_{3}$ (Fig. 5). In the mixture of $330 \mathrm{ppm} \mathrm{NO}$ and $5 \% \mathrm{O}_{2}$, the reduced production of $\mathrm{O}_{3}$ (or $\mathrm{O}$ ) led to higher amount of untreated NO (Fig. 5a). At higher concentrations of $\mathrm{O}_{2}$, the $\mathrm{NO}$ was totally removed and there was still $\mathrm{O}_{3}$ present in the outlet (Fig. 5b). Compared to the case with uncoated electrodes, the $\mathrm{O}_{3}$ concentration remained lower. As a result there was more $\mathrm{NO}_{2}$ in the outlet while the concentration of $\mathrm{N}_{2} \mathrm{O}_{5}$ remained lower (Fig. 5b).

The $\mathrm{TiO}_{2}$ coating started to affect the $\mathrm{NO}_{\mathrm{x}}$ removal only at SIE values higher than $100 \mathrm{~J} / \mathrm{l}$. The growth of SIE increases both the intensity of UV radiation and/or the concentration of atomic oxygen. Higher intensity of UV radiation enhances the photocatalytic effect of $\mathrm{TiO}_{2}$ possibly creating $\mathrm{OH}$ radicals and $\mathrm{O}_{2}^{-}$on the surface [8]. In addition, atomic oxygen can be adsorbed on $\mathrm{TiO}_{2}$ without the activation of surface by UV radiation $[15,16]$. In both cases, $\mathrm{NO}$ will be oxidized to $\mathrm{NO}_{2}$ and $\mathrm{NO}_{3}$ on the surface of $\mathrm{TiO}_{2}$. The importance of adsorption processes was determined by the observation of recovering of the removal properties of $\mathrm{TiO}_{2}$ coating during a break in the reactor operation (15 s - $10 \mathrm{~min})$, whereas longer breaks resulted in increased recovering effect.

The effect of UV radiation was checked by switching off the reactor and illuminating the reactor with $\mathrm{TiO}_{2}$ coating by $\mathrm{Hg}$ lamp $(500 \mathrm{~W})$. A slight decrease of the concentration of NO and growth of concentration of $\mathrm{NO}_{2}$ was recorded. Thus, the $\mathrm{TiO}_{2}$ coating has a small photocatalytic effect. This effect is most likely due to the photocatalytic adsorption of $\mathrm{O}_{2}$ as the $\mathrm{TiO}_{2}$ had no effect when only NO and $\mathrm{N}_{2}$ mixtures were used. However, the increased intensity of UV radiation at higher SIE alone is not able to explain the initial increase in the removal efficiency of $\mathrm{NO}$ and the increase in the concentration of atomic oxygen seems to have a higher impact.

A possible explanation for the temporal effect of $\mathrm{TiO}_{2}$ coating is as follows. Initial enhanced removal of $\mathrm{NO}$ occurs only in the presence of $\mathrm{O}_{2}$ and thus the surface states responsible for the initial removal of $\mathrm{NO}$ have to be initially activated by the presence of $\mathrm{O}$ or $\mathrm{O}_{2}{ }^{-}$adsorbed on $\mathrm{TiO}_{2}$ surface $[8,16]$. When the surface is activated, $\mathrm{NO}$ reacts with the $\mathrm{O}$ or $\mathrm{O}_{2}{ }^{-}$on $\mathrm{TiO}_{2}$ surface whereas the reaction products $\left(\mathrm{NO}_{2}, \mathrm{NO}_{3}\right)$ remain on the surface [8, 16]. As part of $\mathrm{NO}_{\mathrm{x}}$ is now bound to the surface, the concentration of NO in the gas remains lower, and the amount of $\mathrm{O}_{3}$ in the treated gas becomes higher. When the surface states responsible for NO removal are saturated, the oxidation of $\mathrm{NO}$ to $\mathrm{NO}_{2}$ consumes the oxygen species in the 
plasma. If the amount of $\mathrm{O}$ and $\mathrm{O}_{3}$ is insufficient for the oxidation of $\mathrm{NO}$, the concentration of NO starts to increase in the mixture. When the reactor is switched off, the surface of $\mathrm{TiO}_{2}$ will recover in time due to the desorption of $\mathrm{NO}_{\mathrm{x}}$ products.

\section{CONCLUSIONS}

- Without $\mathrm{TiO}_{2}$, the NO removal increased with specific input energy and higher amount of $\mathrm{O}_{2}$. In the presence of $\mathrm{O}_{2}, \mathrm{NO}$ is oxidized initially to $\mathrm{NO}_{2}$ and then to $\mathrm{N}_{2} \mathrm{O}_{5}$. Ozone became detectable when $\mathrm{NO}$ was almost completely converted to $\mathrm{NO}_{2}$.

- Effect of $\mathrm{TiO}_{2}$ coating depended on time. Initially, $\mathrm{TiO}_{2}$ coating enhanced $\mathrm{NO}_{\mathrm{x}}$ removal due to the surface reactions. After few minutes the active surface states saturated and effect of $\mathrm{TiO}_{2}$ coating diminished.

- The main reason for initial increase in the NO removal efficiency is due to adsorption of atomic oxygen whereas photocatalytic effect of $\mathrm{TiO}_{2}$ had only slight effect on the NO removal.

\section{ACKNOWLEDGEMENTS}

This study was financially supported by the Estonian Science Foundation (Grant No. 6654) and Estonian Information Technology Foundation.

\section{REFERENCES}

[1] A.C. Gentile, M.J. Kushner , J. Appl. Phys. 78, 2074 (1995)

[2] B.M. Penetrante, M.C. Hsiao, T. Merritt, G.E. Vogtlin, P.H. Wallman, M. Neiger, O. Wolf, T. Hammer, S. Broer, Appl. Phys. Lett. 68, 3719 (1996)

[3] C.R. McLarnon, B.M. Penetrante, SAE Paper No. 982433 (1998)

[4] I.P. Vinogradov, K. Wiesemann, Plasma Sources Sci. Technol. 6, 307 (1997)

[5] F. Fresnet, G. Baravian, S. Pasquiers, C. Postel, V. Puech, A. Rousseau, M. Rozoy, J. Phys. D: Appl. Phys. 33, 1315 (2000)

[6] S. Barman, L. Philip, Environ. Sci. Technol. 40, 1035 (2006)

[7] T.H. Lim, S.M. Jeong, S.D. Kim, J. Gyenis, J. Photochem. Photobiol. A: Chem. 134, 209 (2000) 
[8] S. Devahasdin, C. Fan, K. Li, D.H. Chen, J. Photochem. Photobiol. A: Chem. 156, 161 (2003)

[9] H.H. Kim, K. Tsunoda, S. Katsura, A.A. Mizuno, IEEE Trans. Plasma. Sci. 35, 1306 (1999)

[10] S. Daito, F. Tochikubo, T. Watanabe, Jpn. J. Appl. Phys. 40, 2475 (2001)

[11] S. Iwasaki, Y. Ehara, H. Kishida, S. Ono, T. Ito, in Symposium of High Pressure, Low Temperature Plasma Chemistry (Hakone IX), 2004, Padua, Italy, 7O-03, p. 6

[12] H. Kim, H. Jun, Y. Sakaguchi, W. Minami, Plasma Sci. Technol. 10, 53 (2008)

[13] O. Guaitella, F. Thevenet, C. Guillard, A. Rousseau, J. Phys. D: Appl. Phys. 39, 2964 (2006)

[14] I. Jõgi, V. Bichevin, M. Laan, A. Haljaste, H. Käämbre, Submitted to: Plasma Chem. Plasma Technol.

[15] O. Guaitella, F. Thevenet, E. Puzenat, C. Guillard, A. Rousseau, Appl. Catal. B: Environm. 89, 296 (2008)

[16] O. Guaitella, K. Allegraud, C. Lazzaroni, A. Rousseau, in XXVII International Conference on Phenomena in Ionized Gases (ICPIG), 2007, edited by J. Schmidt, M. Simek, S. Pekarek, V. Prukner, (Institute of Plasma Physic AS CR, v.v.1, Prague, 2007), 4P06-39, p. 1665 


\section{FIGURE CAPTIONS}

Figure 1. Schematic representation of experimental setup. 1 - capacitive voltage divider, 2 capacitor for the measurement of the charge stored on the dielectric barrier.

Figure 2. Concentration of $\mathrm{NO}, c_{N O}$, in the outlet recorded by the electrochemical NO analyzer as a function of SIE in the case of mixtures with various inlet concentrations of (a) $\mathrm{NO}\left(0 \%\right.$ of $\left.\mathrm{O}_{2}\right)$ and $(\mathrm{b})-\mathrm{O}_{2}(220 \mathrm{ppm}$ of $\mathrm{NO})$. Squares, triangles, circles and crosses denote curves measured at various flow rates or pulse repetition rates. The continuous curves are used as an eye guide whereas dashed lines indicate the initial NO concentration.

Figure 3. Concentrations of $\mathrm{O}_{3}$ and different $\mathrm{NO}_{\mathrm{x}}$ species as a function of SIE in the case of different inlet mixtures: (a) - 330 ppm of $\mathrm{NO}$ and $5 \%$ of $\mathrm{O}_{2}$ : (b) - $220 \mathrm{ppm}$ of $\mathrm{NO}$ and $10 \%$ of $\mathrm{O}_{2}$.

Figure 4. Temporal changes in the case $\mathrm{TiO}_{2}$ coated electrode; (a) - the concentration of remaining $\mathrm{NO}$ at different SIE values (330 ppm NO and $\left.5 \% \mathrm{O}_{2}\right)$; (b), (c) and (d) concentrations of $\mathrm{NO}_{\mathrm{x}}$ species and $\mathrm{O}_{3}$ at $S I E=400 \mathrm{~J} / \mathrm{l}$.

Figure 5. Concentrations of different $\mathrm{NO}_{\mathrm{x}}$ species and $\mathrm{O}_{3}$ as a function of SIE in the case of reactor with $\mathrm{TiO}_{2}$ coated electrode and with different initial gas mixtures: (a) - 330 ppm of $\mathrm{NO}$ and $5 \%$ of $\mathrm{O}_{2}$ : (b) $-220 \mathrm{ppm}$ of $\mathrm{NO}$ and $10 \%$ of $\mathrm{O}_{2}$., In figure $\mathrm{b}$, the concentrations of $\mathrm{NO}_{2}$ and $\mathrm{O}_{3}$ obtained without the $\mathrm{TiO}_{2}$ coating are also indicated for comparison. 


\section{FIGURES}

Jõgi et al. Figure 1.

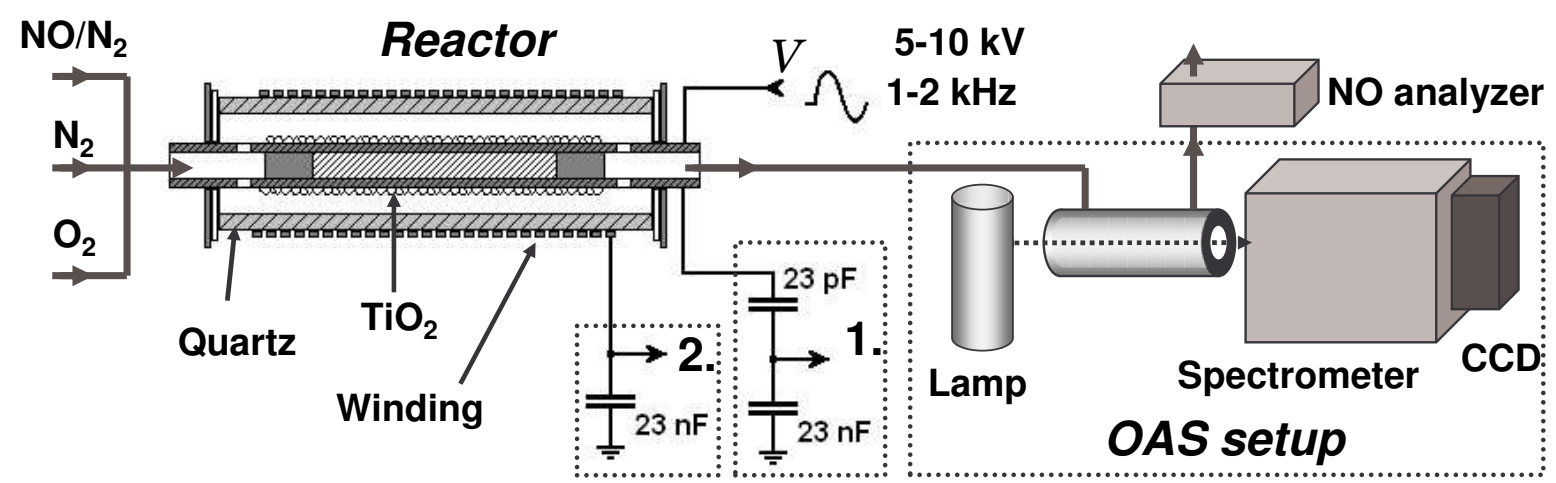


Jõgi et al. Figure 2.
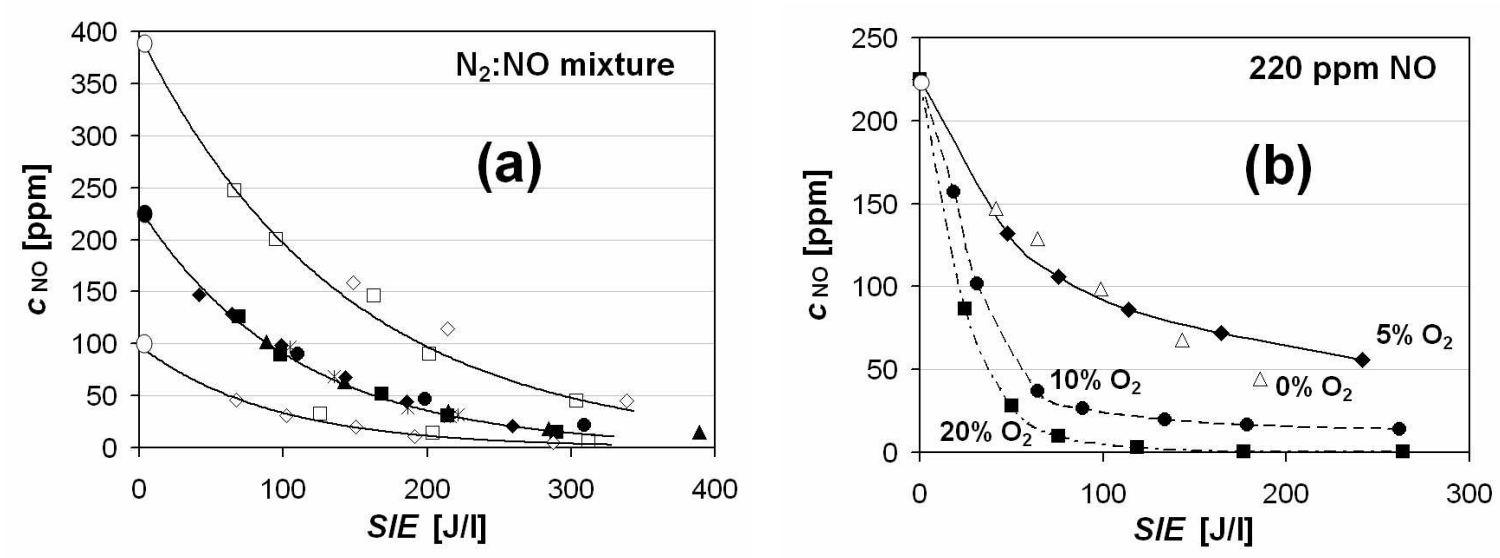
Jõgi et al. Figure 3.
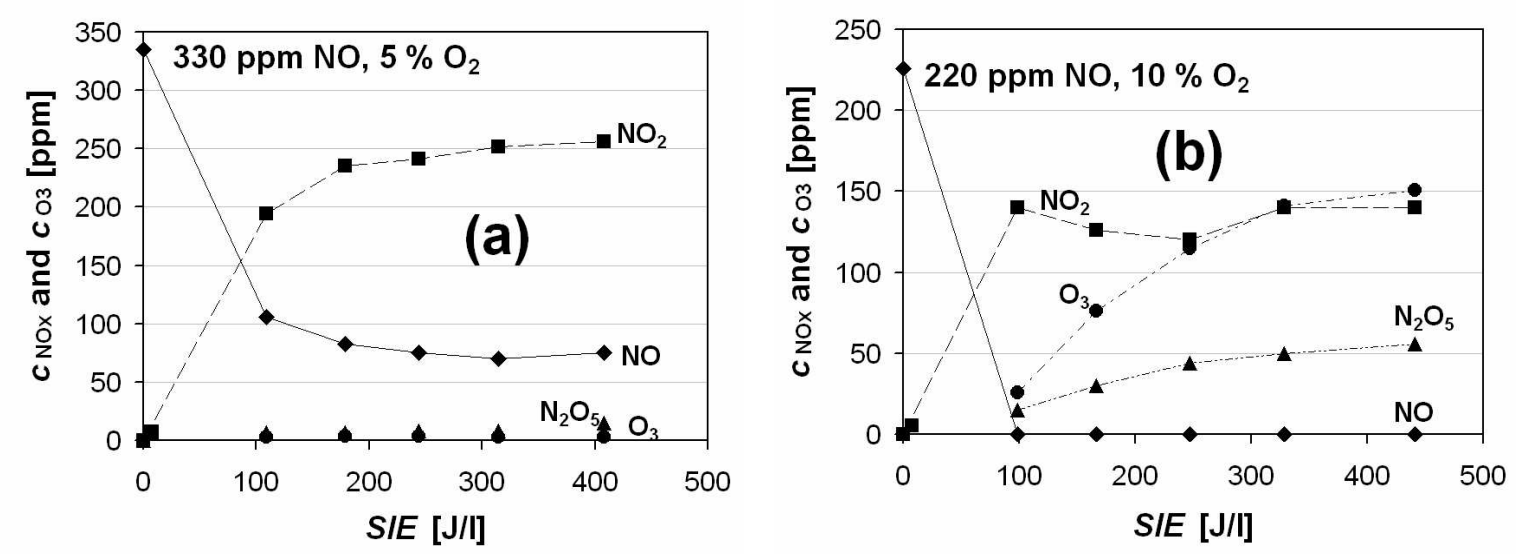
Jõgi et al. Figure 4.
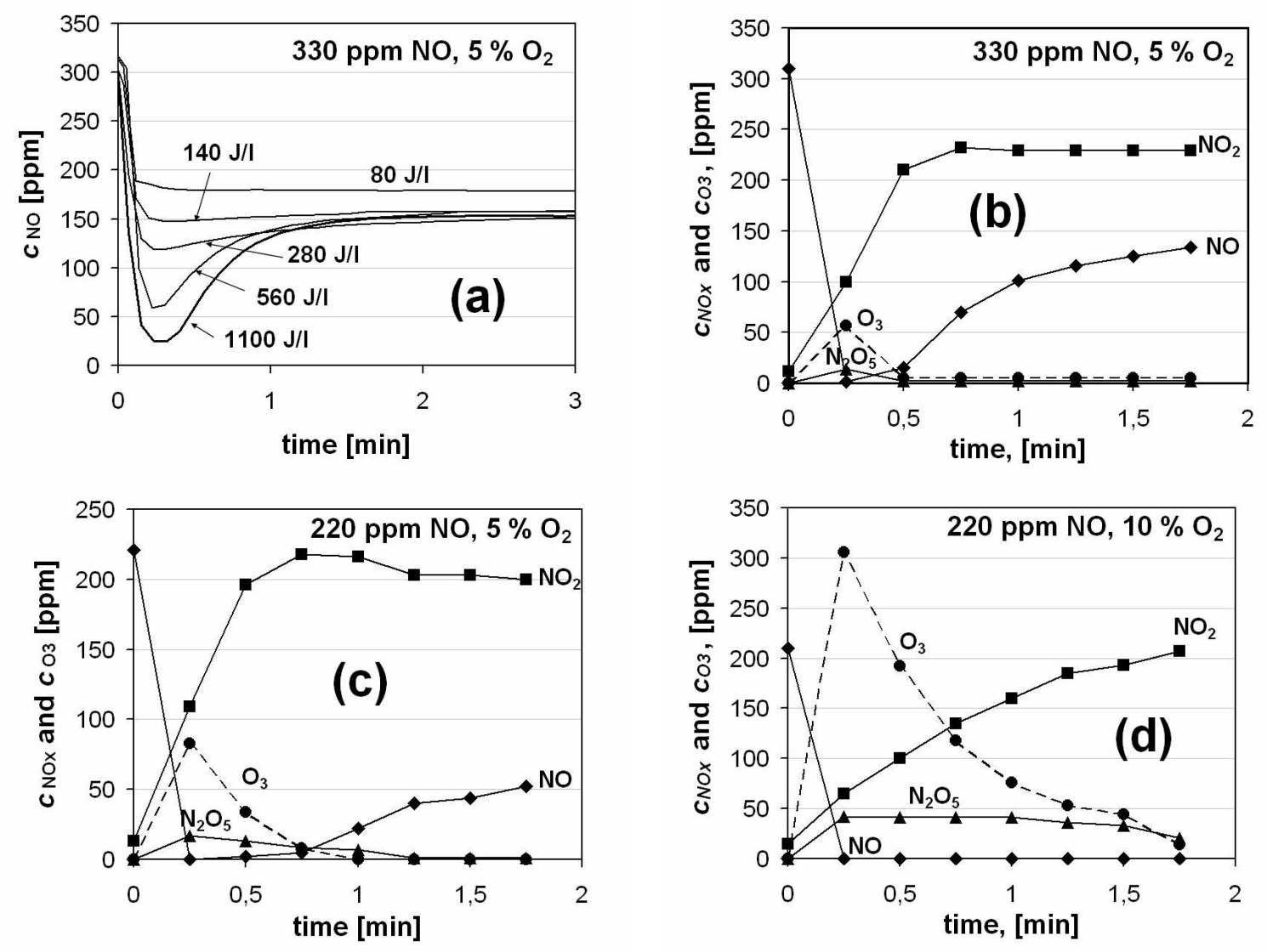
Jõgi et al. Figure 5.
